\title{
Erikoistumiskoulutukset sosiaali- ja terveysalan osaamisen kehittämisen keinona
}

\section{ERIKOISTUMISKOULUTUS KOULUTUSMUOTONA}

Ammattikorkeakoulut ovat järjestäneet erikoistumiskoulutuksia vuodesta 2016 lähtien. Ammattikorkeakoulujen sosiaali- ja terveysalan erikoistumiskoulutukset on suunnattu henkilöille, joilla on sosiaali- ja terveysalalle soveltuva korkeakoulututkinto tai vastaava ammattikorkeakoulututkintoa edeltävä opintoasteen tutkinto. Erikoistumiskoulutuksen tarkoituksena on edistää osallistujan am- matillista kehittymistä ja asiantuntijuuden vahvistumista. Erikoistumiskoulutuksen vähimmäislaajuus on 30 opintopistettä. $(1,2$.)

Sosiaali- ja terveysalalla on 16 ammattikorkeakoulujen erikoistumiskoulutusta (taulukko 1). Näistä ensimmäiset käynnistyivät vuonna 2016. Erikoistumiskoulutuksista 14 on päätynyt toteutusvaiheeseen vuosina 2016-2020.

Taulukko 1. Ammattikorkeakoulujen sosiaali- ja terveysalan erikoistumiskoulutukset $(3,4)$

\begin{tabular}{|c|c|c|c|}
\hline Erikoistumiskoulutus & $\begin{array}{c}\text { Laajuus } \\
\text { (opintopisteet) }\end{array}$ & $\begin{array}{l}\text { Ensimmäinen } \\
\text { toteutusvuosi }\end{array}$ & $\begin{array}{c}\text { Osallistuneet } \\
2016-2019\end{array}$ \\
\hline Aivoterveys & 30 & 2020 & - \\
\hline Asiakas- ja palveluohjaus & 30 & 2020 & - \\
\hline Etäratkaisut kuntoutumisen tukena & 30 & 2018 & 69 \\
\hline Haavahoidon asiantuntija & 30 & 2016 & 694 \\
\hline Hygieniahoitaja & 30 & 2016 & 26 \\
\hline Lastensuojelutyö & 30 & 2017 & 211 \\
\hline Mielenterveys- ja päihdetyö & 30 & 2018 & 224 \\
\hline $\begin{array}{l}\text { Monialainen osaaminen sosiaali- ja terveysalan } \\
\text { digitalisaation kehittämisessä }\end{array}$ & 30 & - & - \\
\hline Moniammatillinen kotikuntoutus & 30 & 2017 & 64 \\
\hline Monikulttuurisuuden asiantuntija & 40 & 2018 & 10 \\
\hline Monikulttuurisen varhaiskasvatuksen asiantuntija & 30 & - & - \\
\hline Palliatiivisen hoidon asiantuntija & 30 & 2020 & - \\
\hline Sairaanhoitajan vastaanottotoiminta & 30 & 2018 & 133 \\
\hline Sosiaali- ja terveysalan palveluiden kehittäjä & 30 & 2017 & 150 \\
\hline $\begin{array}{l}\text { Sosioemotionaalisten taitojen tukeminen } \\
\text { varhaiskasvatuksessa }\end{array}$ & 30 & 2018 & 29 \\
\hline Syöpäpotilaan moniammatillinen hoitoketju & 30 & 2017 & 135 \\
\hline Yhteensä & & & 1745 \\
\hline
\end{tabular}

Korkeakoulujen erikoistumiskoulutuksista tehdyn arvioinnin mukaan erikoistumiskoulutusten vahvuuksia ovat työelämälähtöisyys ja tutkimusperusteisuus. Koulutukset lisäävät osallistujien osaamista ja asiantuntijuutta. Lisäksi osallistujien yhteistyöverkostot ovat laajentuneet erikoistumiskoulutuksissa. (5). 


\section{SOSIAALI- JA TERVEYSALAN AMMATTILAISTEN ARVIO ERIKOISTUMISKOULUTUKSISTA}

Euroopan sosiaalirahaston rahoittama valtakunnallinen sote-alan ammattilaisten jatkuvan oppimisen tiekartta (SOTETIE) -hanke käynnistyi vuonna 2019 ja jatkuu vuoden 2021 loppuun saakka. Hankkeessa kehitetään sosiaali- ja terveysalan ammattilaisille joustava, työelämälähtöinen ja jatkuvaa oppimista tukeva toimintamalli, jota kutsutaan sähköiseksi tiekartaksi. Tavoitteena on, että sähköinen tiekartta helpottaa ammattilaisten osaamisen kehittämistä tulevaisuudessa tarvittavaksi osaamiseksi. (6.) SOTETIE-hankkeen tavoitteet ovat saman suuntaisia opetus- ja kulttuuriministeriön käynnistämän Jatkuvan oppimisen uudistus -hankeen tavoitteiden kanssa. Jatkuvan oppimisen uudistus -hankkeen mukaan jokaisen tulee kehittää osaamistaan aktiivisesti ja joustavasti työuran aikana. (7.)

SOTETIE-hankkeessa kartoitettiin sosiaali- ja terveysalan ammattilaisten näkemyksiä osaamisen kehittämistarpeista. Kartoitusta tehtiin kyselyjen ja työpajojen avulla. Helmi- ja maaliskuussa 2020 toteutettuun Webropol -kyselyyn vastasi 229 sosiaali- ja terveysalan ammattilaista. Vastaajista 127 työskenteli sosiaalialalla, 73 terveysalalla ja 29 sosiaali- ja terveysalalla johto- tai kehittämis- ja suunnittelutehtävissä. (8.)
Kyselyssä sosiaali- ja terveysalan ammattilaiset arvioivat neliportaisella Likert-asteikolla ammattikorkeakoulujen järjestämien erikoistumiskoulutusten (taulukko 2) merkitystä osaamisen kehittämisen näkökulmasta omalla sosiaali- ja terveydenhuollon yhteistyöalueellaan eli yliopistosairaalan erityisvastuualueella, jolla he työskentelivät. Sote-ammattilaisten näkemykset kymmenestä merkittävimmistä erikoistumiskoulutuksista on kuvattu taulukkoon 2 keskiarvon mukaisessa järjestyksessä. (8.)

Mielenterveys- ja päihdetyön sekä Asiakas- ja palveluohjauksen erikoistumiskoulutukset osoittautuivat merkittävimmiksi erikoistumiskoulutuksiksi sekä sosiaali- ja terveysalan että näiden alojen hallinto-, suunnittelu- ja kehittämistehtävissä työskentelevien arvioissa (taulukko 2). Asiakas- ja palveluohjauksen erikoistumiskoulutus käynnistyi useassa ammattikorkeakoulussa tammikuussa 2020 (taulukko 1). Sen sisältöjä ovat asiakas- ja palveluohjauksen lähtökohdat, palvelutarpeiden arvioinnin käytännöt, vuorovaikutussuhteen rakentaminen ja osallisuuden edistäminen, moniammatillinen yhteistyö, sosiaalisesti ja eettisesti kestävä asiakas- ja palveluohjaus sekä asiakas- ja palveluohjauksen kehittäminen. (3).

Taulukko 2. Erikoistumiskoulutusten merkitys SOTE-osaamisen kehittämisessä (8)

\begin{tabular}{|c|c|c|c|c|}
\hline & $\begin{array}{l}\text { Kaikki vastaajat } \\
\text { (N 229) }\end{array}$ & $\begin{array}{l}\text { Sosiaaliala } \\
\text { (n 127) }\end{array}$ & $\begin{array}{l}\text { Terveysala } \\
(\mathbf{n} 73)\end{array}$ & $\begin{array}{l}\text { Muu ala } \\
\text { (mm. SOTE-hallinto) } \\
\text { (n 29) }\end{array}$ \\
\hline 1. & $\begin{array}{l}\text { Mielenterveys- ja } \\
\text { päihdetyö }\end{array}$ & $\begin{array}{l}\text { Mielenterveys- ja } \\
\text { päihdetyö }\end{array}$ & $\begin{array}{l}\text { Mielenterveys- ja } \\
\text { päihdetyö }\end{array}$ & $\begin{array}{l}\text { Asiakas- ja } \\
\text { palveluohjaus }\end{array}$ \\
\hline 2. & Asiakas- ja palveluohjaus & Asiakas- ja palveluohjaus & Asiakas- ja palveluohjaus & Mielenterveys- ja päihdetyö \\
\hline 3. & Lastensuojelutyö & Lastensuojelutyö & $\begin{array}{l}\text { Palliatiivisen hoidon } \\
\text { asiantuntija }\end{array}$ & Lastensuojelutyö \\
\hline 4. & $\begin{array}{l}\text { Sosiaali- ja terveysalan } \\
\text { palveluiden kehittäjä }\end{array}$ & $\begin{array}{l}\text { Sosiaali- ja terveysalan } \\
\text { palveluiden kehittäjä }\end{array}$ & $\begin{array}{l}\text { Syöpäpotilaan } \\
\text { moniammatillinen hoitoketju }\end{array}$ & $\begin{array}{l}\text { Moniammatillinen } \\
\text { kotikuntoutus }\end{array}$ \\
\hline 5. & $\begin{array}{l}\text { Moniammatillinen } \\
\text { kotikuntoutus }\end{array}$ & $\begin{array}{l}\text { Monikulttuurisuuden } \\
\text { asiantuntija }\end{array}$ & $\begin{array}{l}\text { Moniammatillinen } \\
\text { kotikuntoutus }\end{array}$ & $\begin{array}{l}\text { Etäratkaisut kuntoutumisen } \\
\text { tukena }\end{array}$ \\
\hline 6. & $\begin{array}{l}\text { Etäratkaisut kuntoutumisen } \\
\text { tukena }\end{array}$ & $\begin{array}{l}\text { Moniammatillinen } \\
\text { kotikuntoutus }\end{array}$ & Haavahoidon asiantuntija & $\begin{array}{l}\text { Sosiaali- ja terveysalan } \\
\text { palveluiden kehittäjä }\end{array}$ \\
\hline 7. & $\begin{array}{l}\text { Monikulttuurisuuden } \\
\text { asiantuntija }\end{array}$ & $\begin{array}{l}\text { Etäratkaisut kuntoutumisen } \\
\text { tukena }\end{array}$ & $\begin{array}{l}\text { Sairaanhoitajan } \\
\text { vastaanottotoiminta }\end{array}$ & $\begin{array}{l}\text { Palliatiivisen hoidon } \\
\text { asiantuntija }\end{array}$ \\
\hline 8. & $\begin{array}{l}\text { Palliatiivisen hoidon } \\
\text { asiantuntija }\end{array}$ & $\begin{array}{l}\text { Monikulttuurisen } \\
\text { varhaiskasvatuksen } \\
\text { asiantuntija }\end{array}$ & Hygieniahoitaja & $\begin{array}{l}\text { Sairaanhoitajan } \\
\text { vastaanottotoiminta }\end{array}$ \\
\hline 9. & Aivoterveys & $\begin{array}{l}\text { Sosioemotionaalisten } \\
\text { taitojen tukeminen } \\
\text { varhaiskasvatuksessa }\end{array}$ & Lastensuojelutyö & $\begin{array}{l}\text { Sosioemotionaalisten } \\
\text { taitojen tukeminen } \\
\text { varhaiskasvatuksessa }\end{array}$ \\
\hline 10. & $\begin{array}{l}\text { Sosioemotionaalisten } \\
\text { taitojen tukeminen } \\
\text { varhaiskasvatuksessa }\end{array}$ & Aivoterveys & $\begin{array}{l}\text { Sosiaali- ja terveysalan } \\
\text { palveluiden kehittäjä }\end{array}$ & Hygieniahoitaja \\
\hline
\end{tabular}


Kyselyn tulos on vastaava, kun erikoistumiskoulutusten merkitystä osaamisen kehittämisessä tarkastellaan sosiaali- ja terveydenhuollon yhteistyöalueittain (taulukko 3). Mielenterveys- ja päihdetyön sekä Asiakas- ja palveluohjauksen erikoistu- miskoulutukset ovat kärkisijoilla. Eri yhteistyöalueiden sosiaali- ja terveysalan ammattilaisten näkemys alueellaan työskentelevien ammattilaisten osaamisen kehittämistä palvelevista erikoistumiskoulutuksista oli hyvin yhteneväinen.

Taulukko 3. Erikoistumiskoulutusten merkitys yhteistyöalueittain

\begin{tabular}{|c|c|c|c|c|c|}
\hline & $\begin{array}{l}\text { HYKS YT-alue } \\
\text { (n 44) }\end{array}$ & $\begin{array}{l}\text { TYKS YT-alue } \\
(\mathrm{n} 35)\end{array}$ & $\begin{array}{l}\text { TAYS YT-alue } \\
\text { (n 32) }\end{array}$ & $\begin{array}{l}\text { KYS YT-alue } \\
\text { (n 62) }\end{array}$ & $\begin{array}{l}\text { OYS YT-alue } \\
\text { (n 56) }\end{array}$ \\
\hline 1. & $\begin{array}{l}\text { Mielenterveys- ja } \\
\text { päihdetyö }\end{array}$ & $\begin{array}{l}\text { Mielenterveys- ja } \\
\text { päihdetyö }\end{array}$ & $\begin{array}{l}\text { Mielenterveys- ja } \\
\text { päihdetyö }\end{array}$ & $\begin{array}{l}\text { Mielenterveys- ja } \\
\text { päihdetyö }\end{array}$ & $\begin{array}{l}\text { Asiakas- ja } \\
\text { palveluohjaus }\end{array}$ \\
\hline 2. & $\begin{array}{l}\text { Asiakas- ja } \\
\text { palveluohjaus }\end{array}$ & $\begin{array}{l}\text { Asiakas- ja } \\
\text { palveluohjaus }\end{array}$ & $\begin{array}{l}\text { Asiakas- ja } \\
\text { palveluohjaus }\end{array}$ & $\begin{array}{l}\text { Asiakas- ja } \\
\text { palveluohjaus }\end{array}$ & $\begin{array}{l}\text { Mielenterveys- ja } \\
\text { päihdetyö }\end{array}$ \\
\hline 3. & $\begin{array}{l}\text { Sosiaali- ja terveysalan } \\
\text { palveluiden kehittäjä }\end{array}$ & Lastensuojelutyö & $\begin{array}{l}\text { Sosiaali- ja terveysalan } \\
\text { palveluiden kehittäjä }\end{array}$ & Lastensuojelutyö & Lastensuojelutyö \\
\hline 4. & $\begin{array}{l}\text { Monikulttuurisuuden } \\
\text { asiantuntija }\end{array}$ & $\begin{array}{l}\text { Sosiaali- ja terveysalan } \\
\text { palveluiden kehittäjä }\end{array}$ & Lastensuojelutyö & $\begin{array}{l}\text { Moniammatillinen } \\
\text { kotikuntoutus }\end{array}$ & $\begin{array}{l}\text { Sosiaali- ja terveysalan } \\
\text { palveluiden kehittäjä }\end{array}$ \\
\hline 5. & Lastensuojelutyö & $\begin{array}{l}\text { Moniammatillinen } \\
\text { kotikuntoutus }\end{array}$ & $\begin{array}{l}\text { Moniammatillinen } \\
\text { kotikuntoutus }\end{array}$ & $\begin{array}{l}\text { Sosiaali- ja terveysalan } \\
\text { palveluiden kehittäjä }\end{array}$ & $\begin{array}{l}\text { Moniammatillinen } \\
\text { kotikuntoutus }\end{array}$ \\
\hline 6. & $\begin{array}{l}\text { Moniammatillinen } \\
\text { kotikuntoutus }\end{array}$ & $\begin{array}{l}\text { Palliatiivisen hoidon } \\
\text { asiantuntija }\end{array}$ & $\begin{array}{l}\text { Etäratkaisut } \\
\text { kuntoutumisen tukena }\end{array}$ & $\begin{array}{l}\text { Etäratkaisut } \\
\text { kuntoutumisen tukena }\end{array}$ & $\begin{array}{l}\text { Etäratkaisut } \\
\text { kuntoutumisen tukena }\end{array}$ \\
\hline 7. & $\begin{array}{l}\text { Monikulttuurisen } \\
\text { varhaiskasvatuksen } \\
\text { asiantuntija }\end{array}$ & $\begin{array}{l}\text { Syöpäpotilaan } \\
\text { moniammatillinen } \\
\text { hoitoketju }\end{array}$ & $\begin{array}{l}\text { Palliatiivisen hoidon } \\
\text { asiantuntija }\end{array}$ & $\begin{array}{l}\text { Monikulttuurisuuden } \\
\text { asiantuntija }\end{array}$ & $\begin{array}{l}\text { Sosioemotionaalisten } \\
\text { taitojen tukeminen } \\
\text { varhaiskasvatuksessa }\end{array}$ \\
\hline 8. & $\begin{array}{l}\text { Etäratkaisut } \\
\text { kuntoutumisen tukena }\end{array}$ & $\begin{array}{l}\text { Etäratkaisut } \\
\text { kuntoutumisen tukena }\end{array}$ & $\begin{array}{l}\text { Haavahoidon } \\
\text { asiantuntija }\end{array}$ & $\begin{array}{l}\text { Sairaanhoitajan } \\
\text { vastaanottotoiminta }\end{array}$ & $\begin{array}{l}\text { Monikulttuurisuuden } \\
\text { asiantuntija }\end{array}$ \\
\hline 9. & Aivoterveys & Aivoterveys & Hygieniahoitaja & $\begin{array}{l}\text { Syöpäpotilaan } \\
\text { moniammatillinen } \\
\text { hoitoketju }\end{array}$ & Aivoterveys \\
\hline 10. & Hygieniahoitaja & $\begin{array}{l}\text { Monikulttuurisuuden } \\
\text { asiantuntija }\end{array}$ & Aivoterveys & $\begin{array}{l}\text { Palliatiivisen hoidon } \\
\text { asiantuntija }\end{array}$ & $\begin{array}{l}\text { Palliatiivisen hoidon } \\
\text { asiantuntija }\end{array}$ \\
\hline
\end{tabular}

Sosiaali- ja terveysalan ammattilasten arvion mukaan erikoistumiskoulutusten tulee vahvistaa osaamista asiakkaan / potilaan kokonaisvaltaisen hyvinvoinnin ja terveyden, toiminta- ja työkyvyn sekä palvelutarpeiden arvioinnissa. Erikoistumiskoulutusten tulee lisätä myös tutkimus- ja kehittämistyön osaamista. Lisäksi erikoistumiskoulutuksissa tulee ottaa huomioon vaikuttavuuteen ja sen arviointiin liittyvät ammatilliset osaamisalueet. $(4,5$.)

\section{UUSIA ERIKOISTUMISKOULUTUKSIA SOSIAALI- JA TERVEYSALAN OSAAMISEN KEHITTÄMISEEN}

SOTETIE-hankkeessa alkuvuonna 2020 toteutetussa Webropol-kyselyssä ja SOTETIE-hankkeen toimesta järjestetyissä viidessä työpajassa sosiaalija terveysalan ammattilaiset tekivät aloitteita uusista erikoistumiskoulutuksista (8). Kaikille työpajoihin kutsutuille lähetettiin huhtikuussa uusi Webropol-kysely, johon vastasi 216 sosiaali- ja terveysalan ammattilaista. Vastaajista 166 työskenteli sosiaalialalla ja 50 terveysalalla. Kyselyssä sote-ammattilaiset arvioivat seitsemän, alkuvuo- den kyselyssä ja työpajoissa ehdotetun, uuden erikoistumiskoulutuksen merkitystä yhteistyöalueensa sosiaali- ja terveysalan ammattilaisten osaamisen kehittämisessä (taulukko 4).

Ehdotetuista uusista erikoistumiskoulutuksista Kriisi- ja traumatyön erikoistumiskoulutukselle näyttäisi olevan ilmeinen tarve. Kriisi- ja traumatyön osaamista tarvitaan useilla sosiaali- ja terveysalan työkentillä moninaisissa työtehtävissä. Tosin kevään 2020 koronaepidemiasta johtuva poikkeustilanne saattoi vaikuttaa siten, että sosiaali- ja terveysalan ammattilaisten arvion mukaan kriisi- ja traumatyön erikoistumiskoulutukselle oli vankka tarve. Gerontologisen työn erikoistumiskoulutukselle on erityisesti tarvetta terveysalalla, mutta sillä on vastaajien mukaan tarvetta myös sosiaalialalla (taulukko 4.)

Kriisi- ja traumatyön sekä Gerontologisen työn erikoistumiskoulutusten tarve korostuu, kun sosiaali- ja terveysalan ammattilaisten arvioita uusista erikoistumiskoulutuksista tarkastellaan sosiaali- ja terveydenhuollon yhteistyöalueittain. 
Taulukko 4. Uusien erikoistumiskoulutusten merkitys SOTE-osaamisen kehittämisessä (9)

\begin{tabular}{llll}
\hline & Kaikki vastaajat (N 216) & Sosiaaliala (n 166) & Terveysala (n 50) \\
\hline 1. & Kriisi- ja traumatyö & Kriisi- ja traumatyö & Gerontologinen työ \\
\hline 2. & Perhetyö / perhehoitotyö & Perhetyö / perhehoitotyö & Vammais- ja kehitysvammatyö \\
\hline 3. & Gerontologinen työ & Sosiaalinen kuntoutus & Kriisi- ja traumatyö \\
\hline 4. & Vammais- ja kehitysvammatyö & Lastensuojelun laitostyö & Perhetyö / perhehoitotyö \\
\hline 5. & Sosiaalinen kuntoutus & Vammais- ja kehitysvammatyö & Lastensuojelun laitostyö \\
\hline 6. & Lastensuojelun laitostyö & Gerontologinen työ & Sosiaalinen kuntoutus \\
\hline 7. & Tulevaisuuden SOTE-keskustoiminta & Tulevaisuuden SOTE-keskustoiminta & Tulevaisuuden SOTE-keskustoiminta \\
\hline
\end{tabular}

Taulukko 5. Uusien erikoistumiskoulutusten merkitys yhteistyöalueittain osaamisen kehittämisessä

\begin{tabular}{|c|c|c|c|c|c|}
\hline & $\begin{array}{l}\text { HYKS YT-alue } \\
\text { (n 41) }\end{array}$ & $\begin{array}{l}\text { TYKS YT-alue } \\
\text { (n 33) }\end{array}$ & $\begin{array}{l}\text { TAYS YT-alue } \\
\text { (n 32) }\end{array}$ & $\begin{array}{l}\text { KYS YT-alue } \\
\text { (n 57) }\end{array}$ & $\begin{array}{l}\text { OYS YT-alue } \\
(\mathrm{n} 53)\end{array}$ \\
\hline 1. & Kriisi- ja traumatyö & Kriisi- ja traumatyö & Kriisi- ja traumatyö & Kriisi- ja traumatyö & Kriisi- ja traumatyö \\
\hline 2. & $\begin{array}{l}\text { Perhetyö / } \\
\text { perhehoitotyö }\end{array}$ & $\begin{array}{l}\text { Lastensuojelun } \\
\text { laitostyö }\end{array}$ & $\begin{array}{l}\text { Perhetyö / } \\
\text { perhehoitotyö }\end{array}$ & $\begin{array}{l}\text { Perhetyö / } \\
\text { perhehoitotyö }\end{array}$ & Gerontologinen työ \\
\hline 3. & $\begin{array}{l}\text { Vammais- ja } \\
\text { kehitysvammatyö }\end{array}$ & Gerontologinen työ & Gerontologinen työ & Gerontologinen työ & $\begin{array}{l}\text { Vammais- ja } \\
\text { kehitysvammatyö }\end{array}$ \\
\hline 4. & $\begin{array}{l}\text { Lastensuojelun } \\
\text { laitostyö }\end{array}$ & $\begin{array}{l}\text { Perhetyö/ } \\
\text { perhehoitotyö }\end{array}$ & Sosiaalinen kuntoutus & Sosiaalinen kuntoutus & $\begin{array}{l}\text { Perhetyö / } \\
\text { perhehoitotyö }\end{array}$ \\
\hline 5. & $\begin{array}{l}\text { Sosiaalinen } \\
\text { kuntoutus }\end{array}$ & $\begin{array}{l}\text { Vammais- ja } \\
\text { kehitysvammatyö }\end{array}$ & $\begin{array}{l}\text { Vammais- ja } \\
\text { kehitysvammatyö }\end{array}$ & $\begin{array}{l}\text { Lastensuojelun } \\
\text { laitostyö }\end{array}$ & Sosiaalinen kuntoutus \\
\hline 6. & $\begin{array}{l}\text { Tulevaisuuden } \\
\text { sote-keskus toiminta }\end{array}$ & Sosiaalinen kuntoutus & $\begin{array}{l}\text { Lastensuojelun } \\
\text { laitostyö }\end{array}$ & $\begin{array}{l}\text { Vammais- ja } \\
\text { kehitysvammatyö }\end{array}$ & $\begin{array}{l}\text { Tulevaisuuden } \\
\text { sote-keskus toiminta }\end{array}$ \\
\hline 7. & $\begin{array}{l}\text { Gerontologinen } \\
\text { työ }\end{array}$ & $\begin{array}{l}\text { Tulevaisuuden } \\
\text { sote-keskus toiminta }\end{array}$ & $\begin{array}{l}\text { Tulevaisuuden } \\
\text { sote-keskus toiminta }\end{array}$ & $\begin{array}{l}\text { Tulevaisuuden } \\
\text { sote-keskus toiminta }\end{array}$ & $\begin{array}{l}\text { Lastensuojelun } \\
\text { laitostyö }\end{array}$ \\
\hline
\end{tabular}

Lisäksi tarvetta näyttäisi olevan kumpaakin alaa koskevien työ- ja osaamisalueiden erikoistumiskoulutuksille, kuten perhetyön / perhehoitotyön ja vammais- ja kehitysvammatyön erikoistumiskoulutuksille (taulukko 5.)

SOTETIE-hankkeen kyselyjen ja työpajojen avulla saatiin kartoitettua sosiaali- ja terveysalan osaamisalueita, joille tarvitaan erikoistumiskoulutus osaamisen kehittämiseksi. Erikoistumiskoulutusten suunnittelussa on otettava huomioon sosiaali- ja terveysalan yhdyspinnat sekä monialaisen ja -ammatillinen yhteistyön edellyttämä osaaminen. (8.)

\section{AMMATTIKORKEAKOULUJEN SOSIAALI- JA TERVEYS- ALAN ERIKOISTUMISKOULUTUKSIA VALTAKUNNALLISIIN TARPEISIIN}

Taloudellisen yhteistyön ja kehityksen järjestö OECD suosittelee, että Suomi lisäisi aikuiskoulutuksen vastaavuutta työelämän tarpeisiin, jotta sopeutuminen työelämän muutoksiin helpottuisi. Suomessa tulisi OECD:n mukaan muun muassa monipuolistaa koulutustarjontaa ja kehittää räätälöityjä koulutuksia. Sekä Opetus- ja kult- tuuriministeriö että Työ- ja elinkeinoministeriö hyödyntävät OECD:n suosituksia jatkuvan oppimisen uudistuksessa. (12.)

Sosiaali- ja terveysalalla on valtakunnallisia ammatillisen osaamisen kehittämistarpeita esimerkiksi asiakas- ja palveluohjauksen, kriisi- ja traumatyön, mielenterveys- ja päihdetyön sekä gerontologisen työn osaamisalueilla (taulukot 2-5). Sosiaali- ja terveysalan ammattikorkeakoulutusta on 20 Suomen ammattikorkeakoulussa. Erikoistumiskoulutusten suunnittelussa, toteutuksessa, arvioinnissa ja kehittämisessä ammattikorkeakoulut ovat tehneet yhteistyötä. SOTETIEhankkeen kartoitusten perusteella erikoistumiskoulutusten suunnittelua voidaan ja tulee tehdä valtakunnallisten osaamistarvekartoitusten perusteella. Erikoistumiskoulutusten suunnittelu, toteutus, arviointi ja kehittäminen edellyttävät tiivistä yhteistyötä ammattikorkeakoulujen ja sosiaali- ja terveydenhuollon organisaatioiden välillä. Yhteistyötä tehden erikoistumiskoulutuksilla voidaan vastata erikoisosaamisen kehittämisestä valtakunnallisiin tarpeisiin vastaten. 


\section{LÄHTEET}

1) $1438 / 2014$. Valtioneuvoston asetus ammattikorkeakouluista annetun valtioneuvoston asetuksen muuttamisesta. Saatavilla https://www.finlex.fi/fi/laki/ alkup/2014/20141438\#Pidp447193104

2) L 932/2013. Ammattikorkeakoululaki. Saatavilla https://www.finlex.fi/fi/laki/ ajantasa/2014/20140932

3) OPH, Opetushallitus. Erikoistumiskoulutusten julkinen luettelo. Julkinen luettelo ammattikorkeakoulut. Saatavilla 20.9.2020 https://confluence.csc.fi/display/OPHPALV/ Erikoistumiskoulutusten+julkinen+luettelo++ammattikorkeakoulut

4) OPH, Opetushallitus \& OKM, Opetus- ja kulttuuriministeriö. Vipunen. Opetushallinnon tietopalvelu. Ammattikorkeakoulutus. Tutkintoon johtamaton amk-opetus. Erikoistumiskoulutukset - Ammattikorkeakoulut. Koulutukseen osallistuneet. Saatavilla 20.9.2020 https://vipunen. fi/fi-fi/_layouts/15/xlviewer.aspx?id=/fi-fi/ Raportit/Ammattikorkeakoulutus \%20-\%20 tutkintoon $\% 20$ johtamaton $\% 20$ amk-opetus $\% 20$ -\%20erikoistumiskoulutukset.xlsb

5) Rauhala, P. \& Urponen, H. (2019). Selvitys korkeakoulujen erikoistumiskoulutuksista. (Opetus- ja kulttuuriministeriön julkaisuja 2019:17). Helsinki: Opetus- ja kulttuuriministeriö. Saatavilla http://urn.fi/ URN:ISBN:978-952-263-639-3

6) Savonia, Savonia-ammattikorkeakoulu. Tiekartta sote-ammattilaisen jatkuvan oppimisen toteuttamiseen. Saatavilla 20.9.2020 https://blogi. savonia.fi/sotetie/yhteystiedot-ja-toimijat/

7) OKM, Opetus- ja kulttuuriministeriö. Jatkuva oppiminen. Saatavilla 20.9.2020 https://minedu.fi/ jatkuva-oppiminen

8) Helminen J., Markkanen U. \& Säilä T. 2020b. Sosiaali- ja terveysalalla havaittuja osaamisen ja erikoistumisen kehittämistarpeita. SOTETIE-blogi. Savonia-ammattikorkeakoulu. Saatavilla 20.9.2020 https://blogi.savonia.fi/ sotetie/2020/03/27/sosiaali-ja-terveysalallahavaittuja-osaamisen-ja-erikoistumisenkehittamistarpeita/
9) Helminen J., Markkanen U. \& Säilä T. 2020c. Sosiaali- ja terveysalan ehdotuksia erikoistumiskoulutuksiksi. SOTETIEblogi. Savonia-ammattikorkeakoulu. Saatavilla 20.9.2020 https://blogi.savonia.fi/ sotetie/2020/05/26/sosiaali-ja-terveysalanehdotuksia-erikoistumiskoulutuksiksi/

10) Helminen J., Markkanen U. \& Säilä T. 2020d. Sosiaali- ja terveysalan yhteisen osaamisen kehittäminen lisä-, täydennys- ja erikoistumiskoulutuksilla. SOTETIEblogi. Savonia-ammattikorkeakoulu. Saatavilla 20.9.2020 https://blogi.savonia.fi/ sotetie/2020/06/16/sosiaali-ja-terveysalanyhteisen-osaamisen-kehittaminen-lisa-taydennysja-erikoistumiskoulutuksilla/

11) Helminen J., Markkanen U. \& Säilä T. 2020a. Kokemuksia työpajan järjestämisestä ja merkityksestä tiedon tuottamisessa. SOTETIE-blogi. Savonia-ammattikorkeakoulu. Saatavilla 20.9.2020 https://blogi.savonia.fi/ sotetie/2020/04/21/kokemuksia-tyopajanjarjestamisesta-ja-merkityksesta-tiedontuottamisessa/

12) Opetus- ja kulttuuriministeriö \& Työ- ja elinkeinoministeriö. (2020). Tiedote 19.2.2020 9.00. Saatavilla 29.9.2020: https://minedu.fi/artikkeli/-/ asset_publisher/1410877/oecd-kannustaasuomea-kehittamaan-jatkuvaa-oppimistakokonaisuutena

Jari Helminen

YTT, Yliopettaja, Sosiaaliala

Diakonia-ammattikorkeakoulu

Ulla MarkKanen

TtM, Lehtori, Terveyspalvelut

Tampereen ammattikorkeakoulu

TIINA SÄILÄ

TtM, HM, Lehtori, Hyvinvointi- ja terveysteknologia

Tampereen ammattikorkeakoulu 